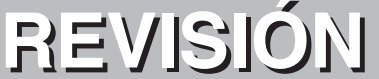

\section{Neural networks to formulate special fats}

\author{
By R.K. Garciaa ${ }^{a}$ K. Moreira Gandra ${ }^{a}$, J.M. Block ${ }^{b}$ and D. Barrera-Arellano ${ }^{a, *}$
}

\author{
${ }^{a}$ Laboratório de Óleos e Gorduras/FEA/UNICAMP. \\ Caixa Postal 6091, Campinas, São Paulo, 13081-970, Brazil \\ ${ }^{b}$ Departamento de Ciência e Tecnologia de Alimentos, CCA/UFSC. \\ Rod. Admar Gonzaga, 1346. Itacorubi. CEP 88034-001 Florianópolis - SC, Brazil. \\ *Corresponding author: daniel@ fea.unicamp.br
}

\section{RESUMEN}

\begin{abstract}
Utilización de redes neuronales para formular grasas técnicas.

Las redes neuronales son una rama de la inteligencia artificial basadas en la estructura y funcionamiento de sistemas biológicos, teniendo como principal característica la capacidad de aprender y generalizar conocimiento. Estas son utilizadas en la resolución de problemas complejos, en los cuales los sistemas computacionales tradicionales presentan una eficiencia baja. Hasta la fecha, han sido propuestas aplicaciones para los más diversos sectores y actividades. En el área de grasas y aceites, la utilización de redes neuronales se ha concentrado principalmente en dos asuntos: la detección de adulteraciones y la formulación de productos grasos. La formulación de grasas para uso específico es el caso clásico de problema complejo donde un experto o grupo de expertos definen las proporciones de cada base, que al ser mezcladas proporcionaran características especificadas para el producto deseado. Algunos sistemas computacionales convencionales están disponibles actualmente para auxiliar a los expertos, sin embargo, estos sistemas presentan algunas deficiencias. En este artículo será descrito con detalles, un sistema para la formulación de productos grasos por redes neuronales (MIX) a partir de 3 o más componentes. Todas las etapas del desarrollo, incluyendo el diseño, construcción, entrenamiento, evaluación y operación de la red serán mostradas.
\end{abstract}

PALABRAS CLAVE: Blending - Formulación - Grasas hidrogenadas - Grasas interesterificadas - Grasas técnicas - Redes neuronales.

\section{SUMMARY}

\section{Neural networks to formulate special fats.}

Neural networks are a branch of artificial intelligence based on the structure and development of biological systems, having as its main characteristic the ability to learn and generalize knowledge. They are used for solving complex problems for which traditional computing systems have a low efficiency. To date, applications have been proposed for different sectors and activities. In the area of fats and oils, the use of neural networks has focused mainly on two issues: the detection of adulteration and the development of fatty products. The formulation of fats for specific uses is the classic case of a complex problem where an expert or group of experts defines the proportions of each base, which, when mixed, provide the specifications for the desired product. Some conventional computer systems are currently available to assist the experts; however, these systems have some shortcomings. This article describes in detail a system for formulating fatty products, shortenings or special fats, from three or more components by using neural networks (MIX). All stages of development, including design, construction, training, evaluation, and operation of the network will be outlined.

KEY-WORDS: Blending - Interesterified fats - Neural networks - Shortenings - Special fats.

\section{INTRODUCTION}

Artificial neural networks (ANNs) are computational systems based on the structure and development of biological systems, which can be defined as a set of highly interconnected, lowcapacity computational units. Because they work in parallel, these systems are able to learn and to generalize knowledge (Romero et al., 1991). ANNs consist of a computer processing technique which is quite useful when there is no exact mathematical information; and they are also able to predict linear and nonlinear problems (Katz et al., 1992).

Neural networks have been proposed to perform various tasks in a number of areas of human knowledge (Poulton, 2002), from medical diagnostics to robotics and also in process control. In the food area, they have been used in chemical and sensory analyses (Sorsa et al., 1991, Arteaga and Nakail, 1993, Liu and Tan, 1999; Haugen, 2001), rheology (Goshawk et al., 1998), microbiology (Lou and Nakai, 2001; Cheroutre-Vialette and Lebert, 2002), to predict the quality of food (Lange and Wittemann, 2002; Ni and Gunasekaran, 1998; Mutlu et al., 2011), in biotechnology (Glassey et al., 1994; Zhang et al., 1994; Yuan and Vanrolleghem, 1999), to monitor the authenticity of food (Da Cruz et al., 2009) and to predict the antioxidant activity and classification of tea (Cimpoiu et al., 2011), among others. 
Most works on neural networks focus on issues related to the detection of adulterations of fats and oils in fat products; however, they have recently been used to optimize processes, such as oil refining, prediction of the stability of oils and mainly in the formulation of fats. Table 1 describes the main applications in this area. The formulation of fats by neural networks has been studied since 1996 (Block et al., 1997), from hydrogenated fats from soybean, using the program MIX (BarreraArellano et al., 2005). The same program was used by Gandra (2011) to build and train a neural network with interesterified soybean-soybean fats and it has shown to be efficient in formulating fats to be used in biscuit fillings.

The growth of the fats industry has demanded an increasing specialization in the production of fatty bases with physical and plastic properties suitable for application in various products. In most cases, conventional methods for the formulation of these products are based on the high degree of specialization of the formulator, which often result in practical responses obtained over time and can cause economic loss or affect product quality.

In other cases, data obtained through equivalent statistical methods, linear programming, or databases is used for the formulation of products. In general, these methods are not precise; they work without cost optimization, and still largely rely on the experience of the formulator.
Therefore, the formulation of fats for specific purposes by neural networks has become an effective alternative compared to conventionally used processes, thus ensuring a high performance of the manufactured products, and allowing the prediction, cost control, and availability of raw materials in the warehouse.

\section{NEURAL NETWORK TECHNOLOGY}

Artificial neural networks can be defined as a set of technologies surrounded by intelligence with the aim of simulating the human brain. In the nineteenth century, Alexander and William James-Bains examined the functioning of the brain and how a set of active neurons is formed and thus created the technology of neural networks (Jansson, 1991). The first model of neural networks that describes how human neurons function was reported by Warren McCulloch and Walter Pitts in 1943 (McCulloch and Pitts, 1943). Their idea of mathematically simulating the human thinking process triggered a huge amount of research in this field during the following two decades.

A neural network is formed of simple processing elements called artificial neurons, which are arranged in layers and interconnected by a high number of connections associated with weight. The aim of the network is to simulate the behavior of

Table 1

Applications of neural networks in fats and oils

\begin{tabular}{|c|c|c|}
\hline Date & Subject & Authors \\
\hline 1991 & Classification of edible oils & Romero et al. \\
\hline 1993 & Adulteration of virgin olive oils & Goodacre et al. \\
\hline 1994 & Adulteration of olive oil & Lichan \\
\hline 1996 & Beef Carcass Classification & Borggaard et al. \\
\hline 1996 & Adulteration of butter fat & Lipp M \\
\hline 1997 & Identification of butter types & Meisel et al. \\
\hline 1997 & Characterization of cocoa butters & Anklam et al. \\
\hline 1997 & Formulation of fats & Block et al. \\
\hline 1998 & Rheology of mayonnaise & Goshawk et al. \\
\hline 1998 & Pork carcass composition & Berg et al. \\
\hline 1998 & Continuous frying control & Huang et al. \\
\hline 1999 & Classification of vegetables oils & Martin et al. \\
\hline 1999 & Mayonnaise & Indahl, U.G. \\
\hline 2000 & Predicting oxidative stability of vegetable oils & Przybylski and Zambiazi \\
\hline 2001 & Classification of iberian pig fats & Carrapiso et al. \\
\hline 2002 & Crystallization of the tripalmitin in olive oil & Gallegos-Infante et al. \\
\hline 2009 & Formulation of special fats with intersterified fats & Gandra et al. \\
\hline 2009 & Optimization of virgin olive oil elaboration process & Márquez et al. \\
\hline 2009 & Checking the authenticity of low-fat yogurts & Da Cruz et al. \\
\hline 2009 & Formulation of blends for margarines with interesterified fats & García et al. \\
\hline
\end{tabular}


biological neurons (Lemes and Junior, 2008; Khataee and Kasiri, 2010).

The main advantage of neural network technology over conventional models is that the ANNs can easily handle complex nonlinear relationships even when the exact nature of such behavior is not well defined (Ni and Gunasekaran, 1998).

The main attraction for the use of ANNs in solving problems in different areas of expertise is their ability to generalize information and learning by example. Generalization is a characteristic associated with the ability to learn from a set of examples and to give consistent responses with unknown data; this demonstrates that ANNs can achieve more than simply mapping the input and output relationships. ANNs are able to extract nonexplicit features of a set of data provided to them as examples. The major features of neural networks are parallel processing, associative and distributive memory, error tolerance, approximation ability, learning, and self-organization, which are properties identical to those of biological neural networks (Gomes and Awruch, 2004, Barbosa et al., 2005).

In the oils and fats industry, software has been used to manage, supervise, and operate product lines such as oil, margarine, butter, and mayonnaise. The automation allows for obtaining better quality products and optimization of costs. In practice, expert systems and neural networks stand out in process control (Brito, 1994).

\subsection{Neural network structure and learning}

Operationally, one can consider the neuronal network as a "processing box" that can be trained to generate one or more outputs from a set of input data (Cerqueira et al. 2001). Between the input and output layers, there is a variable number of hidden (hidden or intermediate) layers. For this arrangement of layers, the number of neurons in each layer and the type of connection between neurons (feedforward or feedback) defines the architecture of the neural network (Haykin, 1999; Vieira et al., 2005; Marini, 2009; Khataee and Kasiri, 2010).

Different neural network architectures are found in the literature. The multilayer perceptron ANN (Multilayer Perceptron - MLP), also known as progressive multilayer network (feedforward), is one of the most widely used because of its versatility and significant results in solving complex problems (Barile et al., 2006; Vafaei et al., 2009; Eyng and Fileti, 2010). A multilayer neural network is typically formed of layers of aligned neurons, with the variables being presented in the first layer, usually referred to as the input layer.

The neurons receive artificial signals and pass them to the intermediate layers of the program through mathematical connections. Each neuron processes one piece of data in parallel and automatically distributes it through the various units comprising the network. The process units transfer the weighed sums of data by an activation function, typically a sigmoidal function, which contains a large number of information signals that are converted into values established during the training and testing steps. The last layer is the output layer, where the solution of the problem is obtained (Sousa et al., 2003; Sofu and Ekinci, 2007; Kruzlicova et al., 2009). Figure 1 shows a basic model of the artificial neural network.

The number of neurons in the input layer corresponds to the number of variables used to feed the neural network. They are often the most important variables for the problem under study. In the output layer, there is a neuron for each response provided by the network. On the other hand, the number of neurons in the intermediate layers depends on the complexity of the problem. Defining the size of these layers is not an easy task, since there is no theoretical method for defining the optimal structure of the neural network. The exact number of layers and hidden neurons is usually estimated by trial and error (Jayas et al., 2000; Vafaei et al., 2009).

The process of learning and knowledge storage is called upgrading. In the literature, there are several proposals of architecture and learning method (Widrow and Lehr, 1990; Hush and Horne, 1993; Rumelhart et al., 1986). The selection of learning method depends on the problem to be solved by the neural network.

The capacity of a neural network depends primarily on its parallel-distributed structure and its ability to learn and, therefore, to generalize. According to Barbosa et al. (2005), some of the important features of neural networks are:

- Error tolerance - this feature allows the network to continue to provide acceptable results in case of failure of some neuron. The information in the network is distributed over all its elements, enabling the retrieval of information contained in the remaining elements in case of destruction of a part of the network.

- Generalization - this allows the neural network to obtain appropriate outputs in response to the unknown input data, i.e., not belonging to the training set of data.

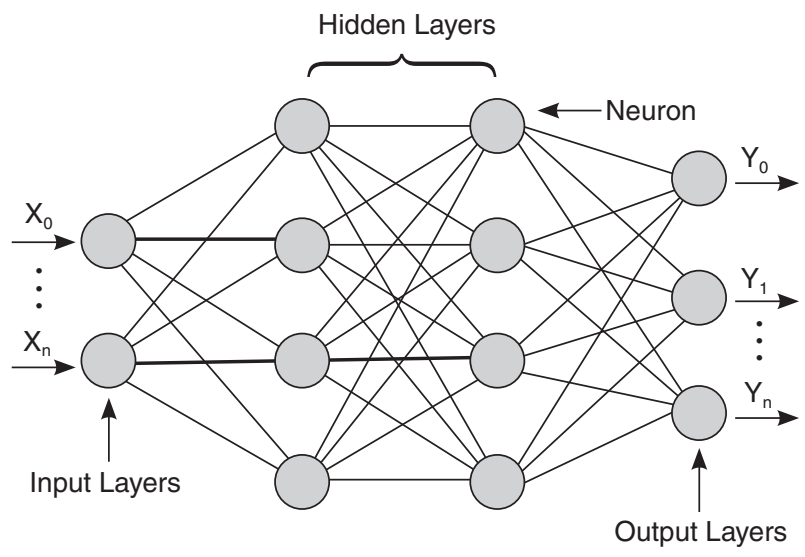

Figure 1

Structure of generalized feedforward and multilayer perceptron ANN. 
- The ability to learn is a process that involves changing the synaptic weights of a neural network by applying a set of training pairs, for which one knows in advance the output one wants to obtain.

- The training is repeated until the network reaches a level where there are no significant changes in the weights.

- Approximation ability - Due to its ability to learn, the network is able to find any point of input/ output, provided the data are representative of the process being dealt with, provided they are properly selected according to the neural network architecture, and from their training algorithm, networks are capable of approximating continuous functions of any order.

\section{SPECIAL FATS}

Special fats are also known as shortenings, and can be defined as fats used for various applications and different purposes, such as emulsification, lubrication, aeration, etc. Initially, the word shortening was used for lard, which was an ingredient used to soften bakery products (O’Brien, 2004).

Currently, due to trends in the use of oils and fats, physical and chemical changes in them are called for, since most natural oils and fats have limited application in their original form due to their particular composition in fatty acids and triacyglycerols. Among the modification processes of oils and fats to produce specialty fats for different purposes, we highlight the modification by genetic engineering, hydrogenation, fractionation, and, more recently, interesterification to produce transfree products (Chiu et al., 2008; Ribeiro et al., 2009).

A common process appraised as an economically viable practice is the mixing of oils and fats known as blending. Blending is a mixture of oils and/or modified or non-modified fats at specific proportions to achieve the desired characteristics of the product. The interactions that occur among the triacyglycerols of the mixtures are responsible for changes in the physical characteristics of fats (Timms, 1985). According to Humphrey and Narine (2004), special fats or shortenings can be composed of a single fat or oil, or a combination of several oils and fats, processed or not for changing their original characteristics, and they may contain emulsifiers, antioxidants and other ingredients added to improve and adapt the product to specific purposes.

The application characteristics of a fat or shortening are directly related to its composition. Fat is formulated taking into account the needs of the process, the functionality required in the foods, and storage conditions of the final product. In general, there are no defined specifications or standards for a particular product, thus, each manufacturer sets its standard formulation and process variables for the manufactured products. However, these products should present some characteristics related to sensory, nutritional, technological aspects, as well as oxidative stability, which ensure quality, applicability and customer satisfaction (Stauffer, 2006).

The most important features of fats and oils are: melting point, the solid fat content (SFC) and crystallization form of the triacyglycerols, influenced not only by the chain length and number of double bonds of fatty acids, but also by the distribution and position of fatty acids in the triacyglycerols (Daniels et al., 2006). The use of physical measures in the oils and fats industry is associated with quality control, research, and the development of new products (Cebula and Smith, 1991).

The solid fat content is essential for characterizing fats and oils for the production of margarines and shortenings, and it is one of the principal parameters taken into account for the formulation of fat products. In addition to defining product hardness and functionality at different temperatures, measuring of the solid fat content allows for controlling the raw materials used in the formulation of the fat (Ramli et al., 2005).

When developing a new product several stages are carried out in a business. These go from defining the application and the consumer market, to the department of new product development to adapting the pilot plant. The importance of the formulation process is critical because the quality of the final product is directly related to the success of the formulation stage. Restrictions related to the production process (availability of raw materials, storage of ingredients, and plant performance) and economic issues (cost of the final product) are also problems faced by formulators (Lefebvre, 1983).

Following the global trend, the oils and fats industry is continuously adding more and more computers to their facilities and process control. This aims at obtaining high quality products at low costs, which compete in a highly competitive market. Fats are widely used in the food industry and, in recent years, the development of these industries has led to an increasing specialization directed to the production of fats with physicalchemical characteristics defined according to their application. These products are usually obtained by using different raw materials, which are mixed in proportions defined by the blending process (Smallwood, 1989).

The set of available bases varies among the different companies as a result of practical responses obtained over time to achieve specifications of new products. The use of bases can minimize the lack or excess of the final product, reducing costs, and the greater the number of bases, the greater the flexibility to meet the specifications of the finished product (O'Brien, 2004).

Despite the technological evolution of the production processes of raw materials, fat formulation procedures, in addition to being quite complex and laborious, are scarcely reported in the literature (Lefebvre, 1983; Zafra, 1993). Despite developments in the field of information technology 
of the 1970s and 1980s, the production of fats by blending still depends on formulators who do a great number of trial and error tests (Lefebvre, 1983; Smallwood, 1989; Erickson and Erickson, 1995).

These formulators are usually based on the solids profile of the available raw materials and of the product to be formulated, they determine the proportion of each raw material, sometimes availing themselves of methods such as statistical equivalents, linear programming, or databases. In general, we can say that these methods are not very accurate, work without optimizing costs and largely continue to rely on the experience of the formulator, which may lead to economic losses, in addition to demanding time and availability of raw materials.

\section{NEURAL NETWORKS FOR FORMULATING SPECIAL FATS}

The incorporation of neural networks in the industrial process provides greater automation and reduces the laboratory work required for preparation by conventional methods. Moreover, by providing multiple solutions for each product neural networks can be useful in research and development.

In order to meet the needs of the fat products industry, the Laboratory of Oils and Fats (UNICAMP, BRAZIL) in collaboration with Cflex company has developed Mix, a software for formulating fats with the help of neural networks (Barrera-Arellano et al., 2005).

This software is divided into Mix Creator and Mix Full. The Mix Creator is used for supplying data on the raw materials used, as well as the formulations used as examples during training; this is made based on data provided by the input layer. The Mix Full, in which the neural network trained with specific fats is inserted, has two tools for searching for formulations: the "formulation search" tool, which locates various formulations with a solids profile and melting point within the range of specific variations (percentage points which may vary at each temperature), and the second one being a tool for "approximate solutions search", which identifies solutions with an approximate profile, i.e. the best profile that can be achieved through fat bases used, although outside the range proposed for SFC.

Block et al. (1997) studied neural networks using the Mix software for the development of fats from three raw materials: one refined soybean oil and two partially hydrogenated soybean fats, based on the solids profile at temperatures of 10, 20, 25, 30,35 , and $37^{\circ} \mathrm{C}$. Figure 2 shows the schematic diagram of training and operation of the artificial neural network.

The efficiency of the neural network in developing special fats and the ability to predict the SFC of formulated fats were presented by Block et al. (1999), and is considered by experts to be

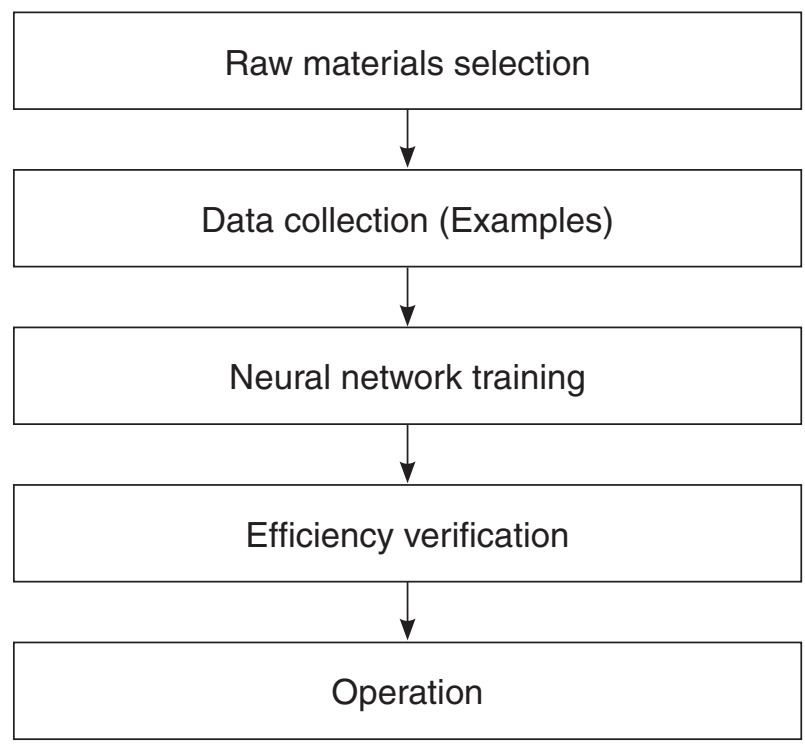

Figure 2

Construction, training and operation process of the artificial neural network.

highly effective in formulating products not included in the training. The authors requested the formulation of 17 products whose solid profiles estimated by the neural network were determined experimentally. In this experiment, the ANN of the perceptron type with sigmoidal activation function comprises two intermediate layers and one output layer. The input layer, which is usually not considered when counting the number of layers, was formed of six variables representing the solids profile of the formulated products. The intermediate layers used six neurons, while the output layer used three neurons, representing the product formulation (percentage of each of the three raw materials proposed for obtaining the desired solids profile in the final product). 112 formulations (examples in Table 2) were used for the neural network training, with data of solid fat content at each temperature being fed to the system. The training process was considered complete when the total error was less than $1 \%$.

In another study, Block et al. (2003) requested responses for some commercial products from the neural network, where the requested response relates to the solids profile of these products. The responses suggested were formulated experimentally, and in

Table 2

Construction, training and operation process of the artificial neural network

\begin{tabular}{|c|c|c|c|c|c|c|c|c|}
\hline \multicolumn{6}{|c|}{ SFC (\%) } & \multicolumn{3}{|c|}{$\begin{array}{c}\text { Formulation } \\
(\%)\end{array}$} \\
\hline $10^{\circ} \mathrm{C}$ & $20^{\circ} \mathrm{C}$ & $25^{\circ} \mathrm{C}$ & $30^{\circ} \mathrm{C}$ & $35^{\circ} \mathrm{C}$ & $37.5^{\circ} \mathrm{C}$ & $A$ & B & C \\
\hline 40.22 & 26.73 & 20.23 & 14.63 & 7.04 & 3.60 & 0 & 70 & 30 \\
\hline 53.01 & 35.89 & 28.41 & 21.26 & 10.48 & 5.69 & 10 & 80 & 10 \\
\hline 26.71 & 15.73 & 11.40 & 7.35 & 2.69 & 0.96 & 0 & 50 & 50 \\
\hline
\end{tabular}


this case, the neural network provided acceptable responses for more than $50 \%$ of the products, which cannot be considered as a low efficiency, since we have to take into account that these products were formulated with either different or more raw materials. In addition to commercial products, three margarines were formulated by conventional methods and by neural networks and then prepared in a pilot plant, where the results obtained by the network were similar to those obtained by conventional methods.

Gandra et al. (2009) built and trained a neural network with interesterified fats for the formulation of special fats for use in trans-free products because of the requirements of the World Health Organization and the laws of several countries recommending their reduction or limiting the amount of trans isomers in food.

In this neural network, the output layer consisted of ten neurons, representing the solids profile at nine temperatures and the dropping point of the formulated products. The input layer used three neurons, representing the product formulation (percentage of each of the three raw materials proposed for obtaining the desired solids profile in the final product). Sixty-three examples of formulations with different raw materials (two interesterified soy-based fats and soybean oil) for training and then the efficiency was shown using examples of blends not inserted into the neural network for training, which showed a high accuracy of the software in predicting the solids profile and the dropping point at each temperature tested.

With the same raw materials, blends for application in hard margarines were formulated. The input data in the Mix Full software were the percentages of solid fat at seven temperatures (10, $20,25,30,35,37.5$, and $45^{\circ} \mathrm{C}$ ) and the melting point of commercial fats for use in margarines. After submitting these data, the network was requested to provide formulations with the same profile of commercial fats. After obtaining the solutions from the neural network, three of them were selected and formulated for evaluation and comparison with commercial fats with regard to solid fat content and melting point. Great variations in the percentage of solids were observed at 10 and $45^{\circ} \mathrm{C}$; however, at intermediate temperatures $\left(20\right.$ to $\left.37.5^{\circ} \mathrm{C}\right)$, the values predicted by the software were similar to those requested. These variations are due to the characteristics of the interesterified soy-based fats, which showed different behaviors from that of fats from other sources, as in the case of commercial fats (García et al., 2010).

Another characteristic of the neural networks described is that for each product to be formulated they provide multiple responses, depending on the variation limits specified for the solid content at each temperature. All these responses can be analyzed from several perspectives: technological, availability of raw materials and costs.

To date, tests have been performed in the manufacturing of margarine, biscuit fillings, puff pastries and cakes, comparing conventional methods with the neural network method with very encouraging results obtained from tests conducted in a pilot plant (García, 2010; Gandra, 2011; Mattioni, 2010; Scaranto, 2010). Currently, neural networks operating with four (Nitatori, et al., 2010) and five raw materials have been built and trained (Barrera-Arellano et al., 2011) as well as neural networks that in addition to considering the solids profile also incorporate the melting point as criterion for selecting the formulations (Gandra, 2011).

\section{CONCLUSION}

Neural networks are beginning to play an important role in the daily life of all human activity, and thus industrial operations are gradually incorporating this technology into their work routines.

The use of neural networks in the formulation of fats for specific uses appears as a powerful tool for the formulators, making their work easier and more efficient, whether it is in research and development or production.

\section{ACKNOWLEDGMENTS}

The authors are grateful to the Brazilian Research Funding Agencies (FAPESP, CAPES and $\mathrm{CNPq}$ ) for financial support.

\section{REFERENCES}

Anklam E, Bassani MR, Eiberger T. 1997. Characterization of cocoa butters and other vegetable fats by pyrolysis mass spectrometry. Fresen. J. Anal. Chem. 357, 981984.

Arteaga GE, Nakail S. 1993. Predicting protein functionality with artificial neural networks: foaming and emulsifying properties. J. Food Sci. 58, 11521156.

Barrera-Arellano D, Akamine EA, Garcia RKA, Gandra KM. 2011. Zero trans fats formulation through a neural network operated with five components: two soybean-soybean interesterified fats, palm, soybean and palm kernel oils. In: 9th Euro Fed Lipid Congress, Rotterdam, The Netherlands, Abstract.

Barrera-Arellano D, Block JM, Grimaldi R, Figueiredo MF, Gomide FAC, Almeida RR. 2005. Programa MIX - Software for the formulation of fats with neural networks. Register INPI 98003155, Campinas, Brazil.

Barbosa AH, Freitas MSR, Neves FA. 2005. Confiabilidade estrutural utilizando 0 método de Monte Carlo e redes neurais. Rev. Esc. de Minas 58, 247-255.

Barile D, Coisson JD, Arlorio M, Rinaldi M. 2006. Identification of production area of Ossolano Italian cheese with chemometric complex approach. Food Control 17, 197-206.

Berg EP, Engel BA, Forrest JC. 1998. Pork carcass composition derived from a neural network model of electromagnetic scans. J. Anim. Sci. 76, 18-22.

Block JM, Barrera-Arellano D, Figueiredo MF, Gomide FC. 1997. Blending process optimization into special 
fat formulation by neural networks. J. Am. Oil Chem. Soc. 74, 1537-1541.

Block JM, Barrera-Arellano D, Figueiredo MF, Gomide FC, Sauer L. 1999. Formulation of special fats by neural networks: A statistical approach. J. Am. Oil Chem. Soc. 76, 1357-1361.

Block JM, Barrera-Arellano D, Almeida R, Gomide FC, Moretti RB. 2003. Formulación de grasas a través de redes neuronales: productos comerciales y producción en planta piloto. Grasas Aceites 54, 240244.

Borggaard C, Madsen NT, Thodberg HH. 1996. In-line image analysis in the slaughter industry, illustrated by Beef Carcass Classification. Meat Sci. 43, 151-163.

Brito LAL. 1994. Importancia de la instrumentación y computarización en programas de calidad total. Aceites y Grasas 15, 99-102.

Carrapiso A, Ventanas J, Jurado A, García C. 2001. An electronic nose to classify Iberian pig fats with different fatty acid composition. J. Am. Oil Chem. Soc. 78, 415-418.

Cebula DJ, Smith KW. 1991. Differential scanning calorimetry of confectionery fats. Pure triglycerides: Effects of cooling and heating rate variation. J. Am. Oil Chem. Soc. 68, 591-595.

Cerqueira EO, Andrade JC, Poppi RJ, Mello C. 2001. Redes Neurais e suas aplicações em calibração multivariada. Quim. Nova 24, 864-873.

Chiu MC, Gioielli LA, Grimaldi R. 2008. Lipídios estruturados obtidos a partir da mistura de gordura de frango, sua estearina e triacilgliceróis de cadeia média, II - pontos de amolecimento e fusão. Quim. Nova 31, 238-243.

Cimpoiu C, Cristea V, Hosu A, Sandru M, Seserman L. 2011. Antioxidant activity prediction and classification of some teas using artificial neural networks. Food Chem. 127, 1323-1328.

Cheroutre-Vialette M, Lebert A. 2002. Application of recurrent neural network to predict bacterial growth in dynamic conditions. Int. J. Food Microbiol. 73, 107118.

Da Cruz AG, Walter EHM, Cadena RS, Faria JAF, Bolini HMA, Franttini-Fileti AM. Monitoring the authenticity of low-fat yogurts by an artificial neural network. $J$. Dairy Sci. 92, 4797-4804.

Daniels RL, Kim HJ, Min DB. 2006. Hydrogenation and interesterification effects on the oxidative stability and melting point of soybean oil. J. Agr. Food Chem. 54, 6011-6015.

Eyng E, Fileti AMF. 2010. Control of absorption columns in the bioethanol process: Influence of measurement uncertainties. Eng. Appl. Artif. Intel. 23, 271-282.

Erickson DR, Erickson MD. 1995. Hydrogenation and base stock formulation procedures, en Erickson DR (ed.) Pratical Handbook of Soybean Processing and Utilization. AOCS Press, Champaign, 218-238.

Gallegos-Infante JA, Rocha-Guzman NE, GonzalezLaredo RF, Rico-Martinez R. 2002. The Kinetics of crystalization of tripalmitin in olive oil: An artificial neural network approach. J. Food Lipids 9, 73-86.

Gandra, KM. 2011. Formulação de gorduras zero trans para recheio de biscoitos utilizando redes neurais. University of Campinas (UNICAMP). Campinas, Brazil.

Gandra KM, García RKA, Block JM, Barrera-Arellano D. 2009. Construction and training of a neural network for the formulation of specialty fats using interesterified fats. In: World Congress on Oils and Fats \& 28th ISF Congress. Oils and fats essential for life - Program \& Abstract Book, Sydney, p 117-118.
Garcia RKA. 2010. Formulação de gorduras para aplicação em margarinas zero trans com redes neurais a partir de gorduras interesterificadas. University of Campinas (UNICAMP). Campinas, Brazil.

García RKA, Gandra KM, Barrera-Arellano D. 2010. Formulação de blends para aplicação em margarinas zero trans por redes neurais baseado no SFC e ponto de fusão de gorduras comerciais. In: V Simpósio Internacional Tendências e Inovações em Tecnologia de Óleos e Gorduras, Campinas, Brazil.

Glassey J, Montague GA, Ward RD, Kara BV. 1994. Artificial neural networks based experimental design procedures for enhancing fermentation development. Biotechnol. Bioeng. 44, 397-405.

Gomes HM, Awruch AM. 2004. Comparison of response surface and neural network with others methods for structural reliability analysis. Struct. Saf. 26, 49-67.

Goodacre R, Kell DB, Bianchi G. 1993. Rapid assessment of the adulteration of virgin olive oils by other seed oils using pyrolysis mass-spectrometry and artificial neural networks. J. Sci. Food Agr. 63, 297-307.

Goshawk JA, Binding DM, Kell DB. 1998. Rheological phenomena occurring during the shearing flow of mayonnaise. J. Rheol. 42, 1537-1553.

Haykin, S. 1999. Neural Networks: A Comprehensive Foundation. Prentice Hall, Englewood Cliffs, NJ.

Haugen JE. 2001. Electronic noses in food analysis, en Rouseff L.R., Cadwallader K.R. (ed.) Headspace analysis of foods and flavors: Theory and Practice (Advancesin Experimental Medicine and Biology). Kluwer Academic Plenum Publishers, New York, 488, 43-57.

Huang Y, Whittaker AD, Lacey RE. 1998. Neural network prediction modeling for a continuous, snack food frying process. T ASAE 41, 1511-1517.

Humphrey KL, Narine SS. 2004. A comparison of lipid shortening functionality as a function of molecular ensemble and shear: Crystallization and melting. Food Res. Int. 37, 11-27.

Hush DR, Horne BG. 1993. Progress in supervised neural networks. IEEE Signal Proc. Mag. 10, 8-39.

Indahl UG, Sahni NS, Kirkhus B, Naes T. 1999. Multivariate strategies for classification based on NIR-spectra - with application to mayonnaise. Chem. Intellig. Lab. Syst. 49, 19-31.

Jayas DS, Paliwal J, Visen NS. 2000. Multi-layer neural networks for image analysis of agricultural products. J. Agr. Eng. Res. 77, 119-128.

Jansson PA. 1991. Neural networks: an overview. Anal. Chem. 63, 357-362

Katz WT, Snell JW, Merickel MB. 1992. Artificial Neural Networks. Method Enzymol. 210, 610-636.

Khataee AR, Kasiri MB. 2010. Artificial neural networks modeling of contaminated water treatment processes by homogeneous and heterogeneous nanocatalysis. J. Mol. Catal. A: Chem. 331, 86-100.

Kruzlicova D, Mocak J, Balla B, Petka J, Farkova M, Havel J. 2009. Classification of Slovak white wines using artificial neural networks and discriminant techniques. Food Chem. 112, 1046-1052

Lange J, Wittmann C. 2002. Enzyme sensor array for the determination of biogenic amines in food samples. Analyt. Bioanalyt. Chem. 372, 276-283.

Lefebvre J. 1983. Finished product formulation. J. Am. Oil Chem. 60, 295-300.

Lemes MR, Junior ADP. 2008. A tabela periódica dos elementos químicos prevista por redes neurais artificiais de kohonen. Quim. Nova 31, 1141-1144. 
Lichan E. Developments in the detection of adulteration of olive oil. 1994. Trends Food Sci. Tech. 5, 3-11.

Lipp M. 1996. Determination of the adulteration of butter fat by its triglyceride composition obtained by GC - A comparison of the suitability of PLS and neural networks. Food Chem. 55, 389-395.

Liu XQ, Tan JL. 1999. Acoustic wave analysis for food crispness evaluation. J. Text. Stud. 30, 397-408.

Lou W, Nakai S. 2001. Artificial neural network-based predictive model for bacterial growth in a simulated medium of modified-atmosphere-packed cooked meat products. J. Agric. Food Chem. 49, 1799-1804.

Marini F. 2009. Artificial neural networks in foodstuff analyses: Trends and perspectives - A review. Anal. Chim. Acta 635, 121-131.

Márquez AJ, Herrera MPA, Ojeda UM, Maza GB. 2009. Neural network as tool for virgin olive oil elaboration process optimization. J. Food Eng. 95, 135-141.

Martin YG, Pavon JLP, Cordero BM. 1999. Classification of vegetable oils by linear discriminant analysis of Electronic Nose data. Anal. Chim. Acta 384, 83-94.

Mattioni B. 2010. Aplicação de redes neurais na formulação de gorduras para massa folhada baseada em gorduras interesterificadas de soja e algodão. University of Santa Catarina. Florianópolis, Brazil.

McCulloch WS, Pitts W. 1943. A logical calculus of the ideas immanent in nervous activity. Bull Math Biophysics 5, 115-133.

Meisel H, Lorenzen PC, Martin D. 1997. Chemometric identification of butter types by analysis of compositional parameters with neural networks. Nahrung 41, 75-80.

Mutlu AC, Boyaci IH, Genis HE, Ozturk R, Basaran-Akgul N, Sanal T, Evlice AK. 2011. Prediction of wheat quality parameters using near-infrared spectroscopy and artificial neural networks. Eur. Food Res. Technol. 233, 267-274

Ni HX, Gunasekaran S. 1998. Food quality prediction with neural networks. Food Technol. 52, 60-65.

Nitatori CY, Gandra KM, Garcia RKA, Barrera-Arellano D. 2010. Construção e treinamento de uma rede neural para formulação de gorduras especiais a partir de gorduras interesterificadas, óleos de soja e palma. In: XVII Congresso de Iniciação Científica da Unicamp, Campinas, Brazil.

O'Brien RD. 2004. Fats and Oils - Formulating and Processing for Applications. CRC Press, New York.

Poulton MM. 2002. Neural networks as an intelligence amplification tool: A review of applications. Geophysics 67, 979-993.

Przybylski R, Zambiazi R. 2000. Predicting Oxidative Stability of Vegetable Oils Using Neural Network System and Endogenous Oil Components. J. Am. Oil Chem. Soc. 77, 925-931.

Ramli N, Said M, Loon NT. 2005. Physicochemical characteristics of binary mixtures of hydrogenated palm kernel oil and Goat milk fat. J. Food Lipids 12, 243-260.
Ribeiro APB, Masuchi MH, Grimaldi R, Gonçalves LAG. 2009. Interesterificação química de óleo de soja e óleo de soja totalmente hidrogenado: influência do tempo de reação. Quim Nova 32, 939-945.

Romero RAF, Lanças FM, Guizo SJ, Berton SR. 1991. Classification of edible oils using neural networks. Proceedings/Anais of International Meeting on Fats and Oils Technology - Symposium and Exhibition, Campinas, Brazil, 9-11.

Rumelhart DE, Hinton GE, Williams RJ. 1986. Learning internal representations by error propagation. En: Rumelhart DE, McClelland JL (ed) Parallel Distribuited Processing: Explorations in the Microstruture of Cognition. MIT Press, Cambridge, 318-362.

Scaranto BAA. 2010. Aplicação de redes neurais na formulação de gorduras para bolo baseada em gorduras interesterificadas de soja e algodão. University of Santa Catarina, Florianópolis, Brazil.

Smallwood NJ. 1989. Using computers for oil blending. J. Am. Oil Chem. Soc. 66, 644-648.

Sofu A, Ekinci FY. 2007. Estimation of Storage Time of Yogurt with Artificial Neural Network Modeling. J. Dairy Sci. 90, 3118-3125.

Sorsa T, Koivo H, Koivisto H. 1991. Neural networks in process fault diagnosis. IEEE Trans. Systems Man, and Cybernetics 21, 815-825.

Sousa EA, Teixeira LCV, Mello MRPA, Torres EAFS, Neto JMM. 2003. Aplicação de redes neurais para avaliação do teor de carne mecanicamente separada em salsicha de frango. Ciênc. e Tecnol. de Alim. 23, 307-311.

Stauffer CE. 2006. Uso de las grasas y los aceites en productos de panadería y confíteria. Grasas Aceites 3, 420-432.

Timms RE. 1985. Physical properties of oils and mixture. J. Am. Oil Chem. Soc. 62, 241-248.

Widrow B, Lehr M. 1990. 30 years of adaptive neural networks: perceptron, madaline, and backpropagation. Proceedings of IEEE 78, 14151442.

Vafaei MT, Eslamloueyan R, Ayatollahi SH. 2009. Simulation of steam distillation process using neural networks. Chem. Eng. Res. Des. 87, 997-1002

Vieira WG, Santos VML, Carvalho FR, Pereira JAFR, Fileti AMF. 2005. Identification and predictive control of a FCC unit using a MIMO neural model. Chem. Eng. Process 44, 855-868.

Yuan JQ, Vanrolleghem PA. 1999. Rolling learningprediction of product formation in bioprocesses. J. Biotechnol. 69, 47-62.

Zafra A. 1993. Automation and refining. Inform 4, 166.

Zhang Q, Reid JF, Litchfield B, Ren J, Chang S. 1994. A prototype neural network supervised control system for Bacillus thuringiensis fermentations. Biotechnol. Bioeng. 43, 483-489. 